\title{
Experimental Investigation of Pull-Out and Shear Behavior of Lifting Sockets in Precast UHPC Panels
}

\author{
Muhammed Marasli $^{1}$ iD, Serkan Subasi ${ }^{2}$ iD, Heydar Dehghanpour $^{3 *}$ iD Volkan Ozdal $^{4}$ iD, Beni \\ Kohen $^{5}$ iD \\ 1,3,4,5 Fibrobeton Company, Istanbul, Turkey \\ ${ }^{2}$ Düzce University, Engineering Faculty, Civil Engineering Department, Duzce, Turkey. \\ *heydar.dehghanpour@yahoo.com
}

\section{Abstract}

The increasing demands and needs of human beings reveal the need to increase the performance of construction techniques and materials in the construction sector. Recently, the use of ultra high performance concrete (UHPC) on building facades has been increasing due to their superior mechanical and physical properties. Since UHPC products are relatively heavy, it is important to examine the lifting apparatuses for safety. In this study, pull-out and shear behavior of lifting sockets embedded in UHP precast panels produced in real geometry and dimensions were investigated. UHPCs consist of two different mixtures as $A$ and $B$. Two different types of lifting sockets with the trade names RD and TF were used. Pullout and shear test results proved that lifting sockets are sufficient as safety in both mixtures. The results obtained can contribute to the literature in this area and provide insight into the reliable lifting and handling procedure of precast facade panels.

Keywords: UHPC, lifting socket, pull-out, shear, precast panel

\section{Prekast UHPC Panellerindeki Kaldırma Soketlerinin Çekme-Çıkarma ve Kesme Davranışının Deneysel Olarak İncelenmesi}

\begin{abstract}
Özet
İnsanoğlunun artan istek ve ihtiyaçları, inşaat sektöründe yapı teknikleri ve malzemelerinin performansının artırılması intiyacını ortaya koymaktadır. Son zamanlarda, bina cephelerinde ultra yüksek performanslı beton (UHPC) kullanımı üstün mekanik ve fiziksel özellikleri nedeniyle artmaktadır. UHPC ürünleri nispeten ağır olduklarından dolayı kaldırma aparatlarının güvenlik açısından incelenmesi önem arz etmektedir. Bu çalışmada gerçek geometri ve boyutlarda üretilen UHPC prekast panellerine gömülü olan kaldırma soketlerinin çekme-çıkarma ve kesme kuvvetlerine karşı davranışları incelenmiştir. UHPC paneller A ve B olmak üzere iki farklı karışımdan elde edilmiştir. Ticari isimleri RD ve TF olan iki farklı tip kaldırma soketi kullanımıştır. Çekme-çıkarma ve kesme test sonuçları kaldırma soketlerinin her iki karışımda da güvenlik açısından yeterli olduğunu kanıtlamıştır. Elde edilen sonuçlar, literatüre bu alanda katkı sağlayabilir ve prekast cephe panellerinin güvenilir bir şekilde kaldırma ve taşıma prosedüründe fikir oluşturabilir.
\end{abstract}

Anahtar Kelimeler: UHPC, kaldırma soketi, çekme-çıkarma, kesme; prekast panel 


\section{INTRODUCTION}

Recently, the application of ultra high performance concretes (UHPCs) as precast panels for building facades has become widespread. UHPCs are concrete types that have many advantages in terms of both structural, durability and architecture. High strength and modulus of elasticity, continuity and long life, low creep, low permeability and long-term cost reduction are most important of the features of ultra-high performance concretes (UHPCs). The most important usage areas of UHPCs can be modern building facades, shell structural elements and bridge elements. In the last two decades, with significant developments in concrete technology, significant efforts have been made for UHPCs that can be used in modern bridge engineering [1, 2]. According to different classifications, the compressive strength of UHPCs should be over $120 \mathrm{MP}$. In order to produce such a concrete, fine aggregate $(<5 \mathrm{~mm})$, micro silica fume, high performance cements and other powder additives must be included in the mixture $[3,4]$. To significantly reduce the water need, select SP additives must be used. Also, the flexural, tensile and shear strength of the UHPC to be produced can be increased by adding an amount of fibers that do not adversely affect the compressive strength. Considering the number of articles published on UHPCs related since 2015, a significant increase is observed. This shows how much application potential UHPCs have in the construction industry [3]. In addition, the durability of UHPCs against chemical and physical factors has been examined by many researchers and it has been confirmed that they have superior performance compared to conventional concretes [5-7].

For the production of UHPC, Portland cement with a strength class of CEM I 42.5 MPa or CEM I 52.5 $\mathrm{MPa}$ and low $\mathrm{C} 3 \mathrm{~A}$ ratio is generally preferred. In order to eliminate the brittleness due to high compressive strength, approximately $2 \%$ of steel fibers are used in volume. C-S-H gels are formed as a result of the reaction of slaked lime formed as a result of cement hydration with silica fume. Silica fume fills even the very fine spaces between cement and aggregates, creating a denser, more homogeneous, tighter micro structure and a high strength matrix. Microstructure develops due to pozzolanic reactions between $\mathrm{C}-\mathrm{H}$ resulting from hydration of cement and complementary materials such as silica fume and nanosilica [8]. Well-chosen steel fiber dosage can increase ductility and reduce autogenous shrinkage of UHPC, which is very important especially for fragile materials. Adding the amount of steel fiber can increase the tensile stresses of the concrete, but the added high amount of fiber can reduce the workability of the UHPC mixture and cause a decrease in the compressive strength [9].

Steel sockets are embedded in UHPC elements produced for building facades for both carrying-lifting and mounting purposes. In either case, the bond level between the socket and the UHPC is very important as security. The bond between the embedded socket and the UHPC is directly related to the adherence strength. The adherence between concrete and steel socket consists of three main parts; Chemical bond, slip and geometry of the socket. The chemical part is related to content of concrete and additives used and should not be ignored [10]. Superplasticizer additives used can have a positive or negative effect between the socket and the UHPC. Using the optimum amount of pozzolanic additives can increase the contact area between the socket and UHPC and lead to the development of adherence strength. In the design of cementbased structural elements, the bond level between the steel bar and the matrix has an important effect as engineering, and for this reason, it is very important to carry out different analysis and experimental studies in this area [11-13].

In this study, pull-out and shear tests of two types of sockets used in UHPC precast panels applied in real size and geometry were experimentally considered. The sockets are used for convenience during carrying and lifting by connecting with the crane. The aim of this study is to examine the connection of sockets with UHPC composites in order to avoid possible safety problems during lifting at the construction site. Studies conducted for similar purposes in the literature are quite limited. Therefore, the results obtained in this study will contribute to closing the gaps in the literature in this field. 


\section{EXPERIMENTAL}

\subsection{Materials}

Precast facade panels are produced from two different UHPC mixtures. CEM I / $52.5 \mathrm{R}$ white Portland cement has been used as a binder in the mixtures. Silica sand with a grain size range of $90-850 \mu \mathrm{m}$ and quartz powder with a grain size range of $2-850 \mu \mathrm{m}$ were used as filling material. The $\mathrm{SiO} 2$ content of the quartz sand used is $96 \%$ (minimum), its specific gravity and specific surface area are $2.2 \mathrm{~g} / \mathrm{cm} 3$ and $15 \mathrm{~m} 2 / \mathrm{g}$ (minimum), respectively. Microwhite silica fume (SF) was added to the mixtures as pozzolanic material. This pozzolanic material is often used to improve the properties and performance of high performance concrete and specialty mortar formulations. This SF, which is also reactive, is often used to improve the properties and performance of high performance concrete and special mortar formulations. Stainless micro steel fiber (MSF) with a length of $12.5 \mathrm{~mm}$ and a diameter of $0.175 \mathrm{~mm}$ was preferred as the fiber in mixtures. The tensile strength and modulus of elasticity of the fiber used are $2800 \mathrm{MPa}$ and $210 \mathrm{GP}$, respectively. Polycarboxylate ether based plasticizer was used in all mixtures. Two types of sockets known as RD and TF were used. RD socket had a Diameter of $12 \mathrm{~mm}$ and a length of $300 \mathrm{~mm}$. Also, TF socket had a Diameter of $15 \mathrm{~mm}$ and a length of $70 \mathrm{~mm}$. The connecting portions of both sockets had diameters of $17 \mathrm{~mm}$. After the sockets were fixed on wooden molds in $40 \times 25 \times 7 \mathrm{~cm}$ dimensions as shown in Fig. 1 , prepared UHPC mixtures were placed in the molds. For each test, 3 samples were produced from the same mixture. Since the main aim of this study is to determine the load capacity carried by the lifting sockets used, it was not deemed appropriate to share the mixture detail also due to the company's privacy policy.

a)

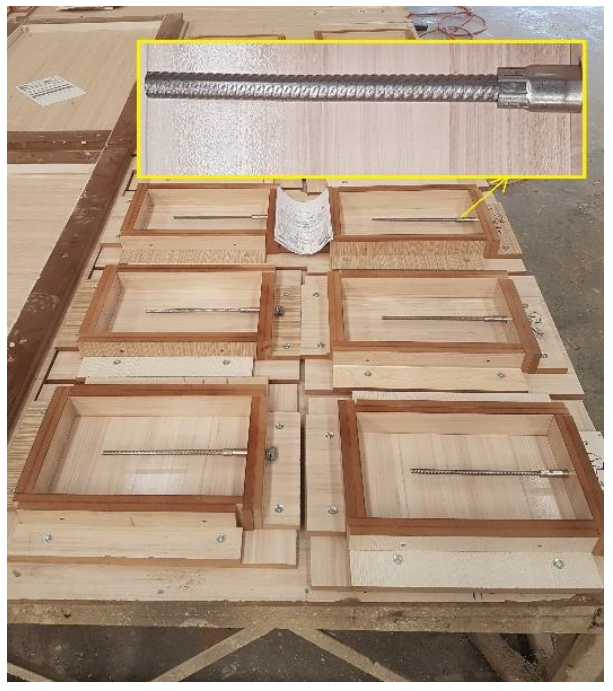

b)

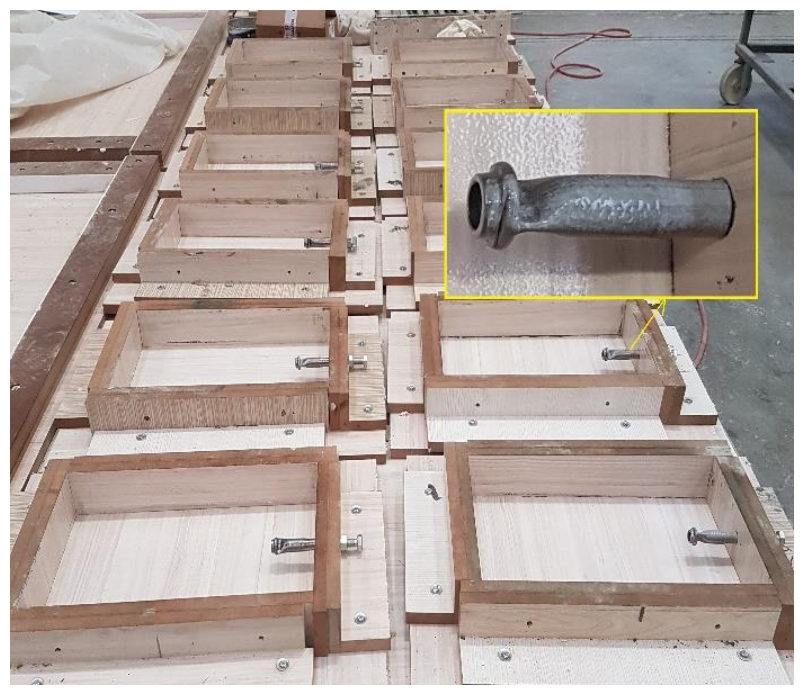

Fig. 1. RD (a) and TF (b) socket connected molds.

\subsection{Test Methods}

Pull-out and shear test methods were performed on the precast panel samples produced. Test setup image for both test methods is given in Fig. 2. For the realization of pull-out and shear tests, suitable support apparatuses were previously prepared and mounted on the device in order to ensure that the samples were attached to the test device as fixed. The apparatus used in the pull-out test setup was L-shaped, the horizontal part was fixed to the device, and the plate sample was fixed to the vertical part (Fig. 2-a). A bolt-shaped apparatus was connected to the hole of the socket embedded in the sample and subjected to tensile with a 10-ton universal test device. Pull-out tests are generally performed on cubic or cylindrical samples in accordance with standards such as ASTM C900 [14], ACI 440.3R-04 [15], CAN/CSA S806-02 [16] and 
ASTM C234 [17]. However, the samples used in this study were produced in real size, to be applied in Fibrobeton's own projects. In the shear test, the sample was placed horizontally on the apparatus fixed to the device and connected to the apparatus with rigid elements (Fig. 2-b). A bolt-shaped apparatus was attached to the hole of the socket embedded in the sample and subjected to a tensile load perpendicular to the socket. Images in Fig 2 are typically given. The connection types were the same for the precast plates (RD and TF and A-B mixes) used in all tests. The RD socket was $300 \mathrm{~mm}$ long, $12 \mathrm{~mm}$ diameter ribbed anchor type and the TF was $70 \mathrm{~mm}$ long, $15 \mathrm{~mm}$ diameter flat pipe type. However, as shown in the figure, the end of the TF socket has been crushed in a special way and made recessed-protruding for better adherence in the concrete.
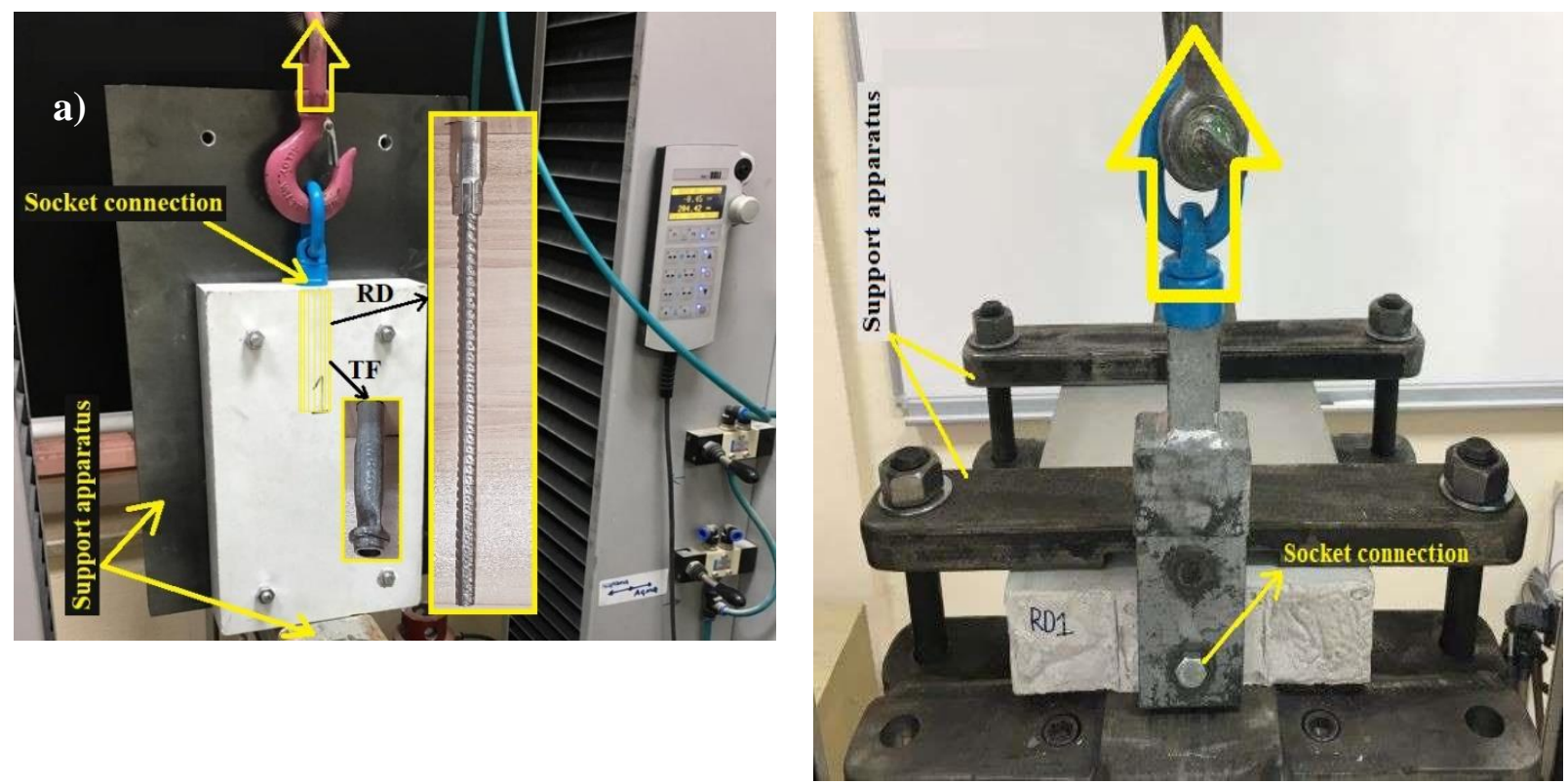

Fig. 2. Pull-out (a) and shear (b) test setups.

\section{Results and Discussion}

Slump flow diameters of the produced A and B UHPC mixtures were measured as 240 and $235 \mathrm{~mm}$, respectively, according to the ASTM-C 1611 / C 1611M - 05 standard [18]. Also, compressive and flexural strengths were obtained as 116 and $18.5 \mathrm{MPa}$ for mixture A and 140 and $19.5 \mathrm{MPa}$ for mixture $\mathrm{B}$, respectively. According to EN 206: 2013 standard, the compressive strength of the UHPC should be above $100 \mathrm{MPa}$ [3]. Also, ASTM C1856 [19] has specified the compressive strength of UHPC at least $120 \mathrm{MPa}$ and the amount of slump flow between $20-25 \mathrm{~mm}$.

The force-displacement curves obtained after the pull-out test applied to two different lifting sockets embedded in two different UHPC precast panels are compared in Fig 3. According to the results, RD socket showed a higher pull-out strength than TF. When the RD embedded A and B mixtures were compared, the pull-out strength of the panel obtained from the B mixture was found to be $15 \%$ higher than the panel obtained from the A mixture. Mix B contains more fiber than A, and this difference in strength may be due to this. Also, the displacement behavior of the panel produced from the B mixture after the pull-out experiment was $17 \%$ more than A. The strength of the RD socket embedded in the A mixture first decreased rapidly and increased again at about $28 \mathrm{~mm}$ displacement. This is because the fibers intervene and prevent the socket from being removed. 
Considering the pull-out behavior of the TF sockets in A and B mixtures, behaviors similar to that of the mix difference in RD sockets were observed. In other words, both maximum pull-out strength and displacement values of the panels consisting of B mixture were higher than A. The maximum load value and maximum displacement value of TF-B panel were high than TF-A panel, as \% 38 and \% 50, respectively. When the pull-out maximum load level is compared according to the socket type, the lifting load of the RD type socket was $94 \%$ higher in the A mixes than the TF type socket. Also, the lifting load of the RD type socket was 58\% higher than the TF type socket in the B mixes. Similarly, the RD socket showed 36\% displacement in the A mix and 6\% in the B mix, more than the TF socket.

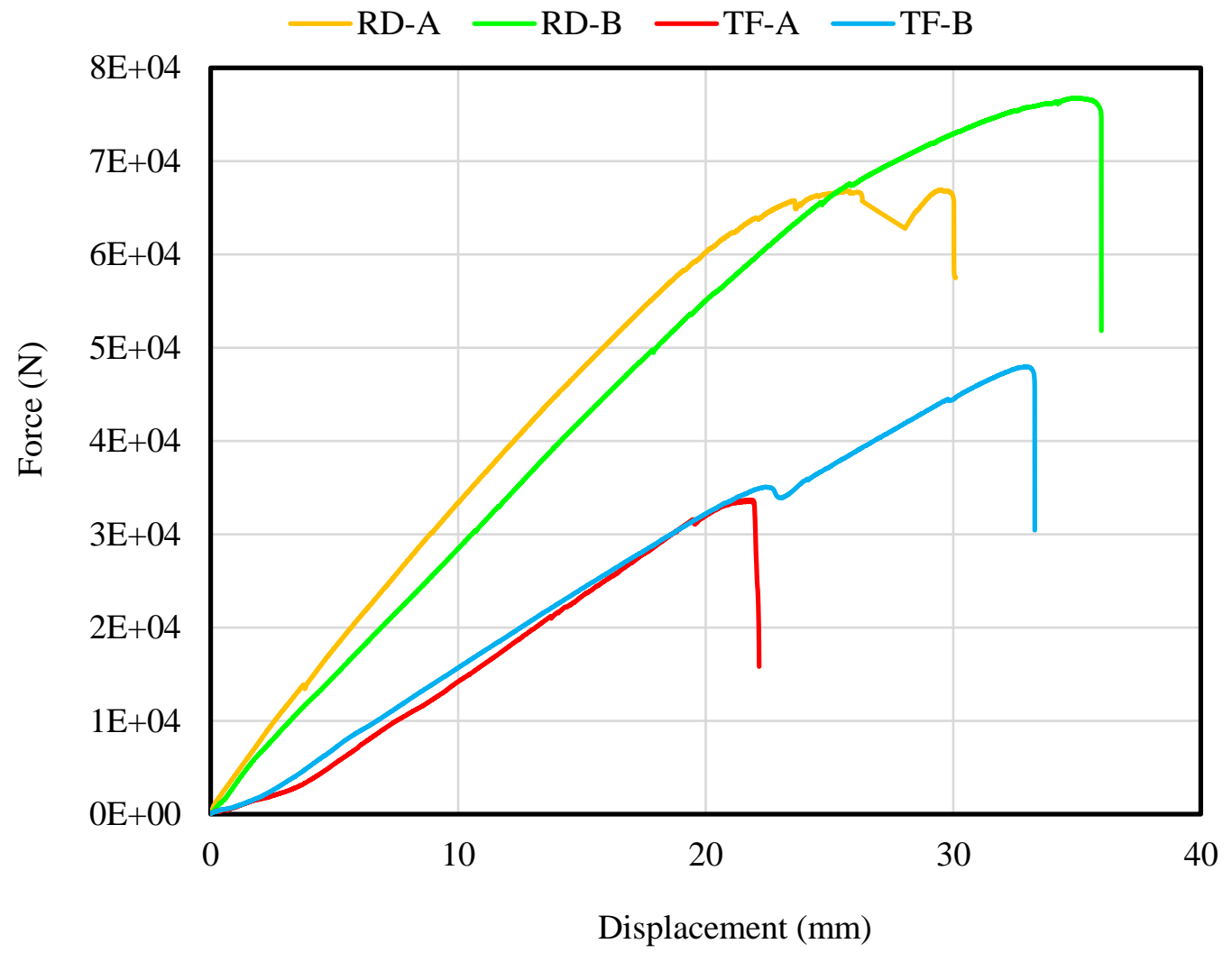

Fig. 3. Force-displacement curves of two different lifting sockets after pull-out test.

The damaged views of precast UHPC panels containing two different socket (RD and TF) types produced from two different mixtures (A and B) are given in Fig. 4. As the slipping continued, the ribbed anchor was constantly stopped with the steel fibers in the UHPC mixture, increasing the amount of load. Considering the RD-A, as shown Fig. 3, the interaction between the socket and the concrete completely disappeared, with a crack formed in the specimen parallel to the socket ( Fig. 4) after the maximum load was obtained after approximately $28 \mathrm{~mm}$ slipping. Similarly, in the RD-B sample, the amount of load has been increased as the socket slipped. After $76.7 \mathrm{kN}$ loading, approximately $36 \mathrm{~mm}$ slip was observed in the socket. In this case, the socket came to its ultimate strength and suddenly broke. However, no damage was observed in the UHPC sample. This is related to the fact that the B mixture is stronger than the A mixture, as mentioned above. The damaged images of TF-A and TF-B samples were similar, however, as with the RD samples, the TF socket showed greater resistance to tensile load in B mixture. Mixture A deformed after the TF socket slipped $22 \mathrm{~mm}$, whereas the sample with mix B was deformed after the socket slipped $33 \mathrm{~mm}$. As a result, a great effect of steel fibers against slipping of sockets through concrete was observed. This interaction is provided by ribs in RD sockets and recessed-protruding in TF sockets. Many studies have 
confirmed that steel fibers increase the toughness of the concrete and improve the adhesion between the reinforcing elements [20-22].
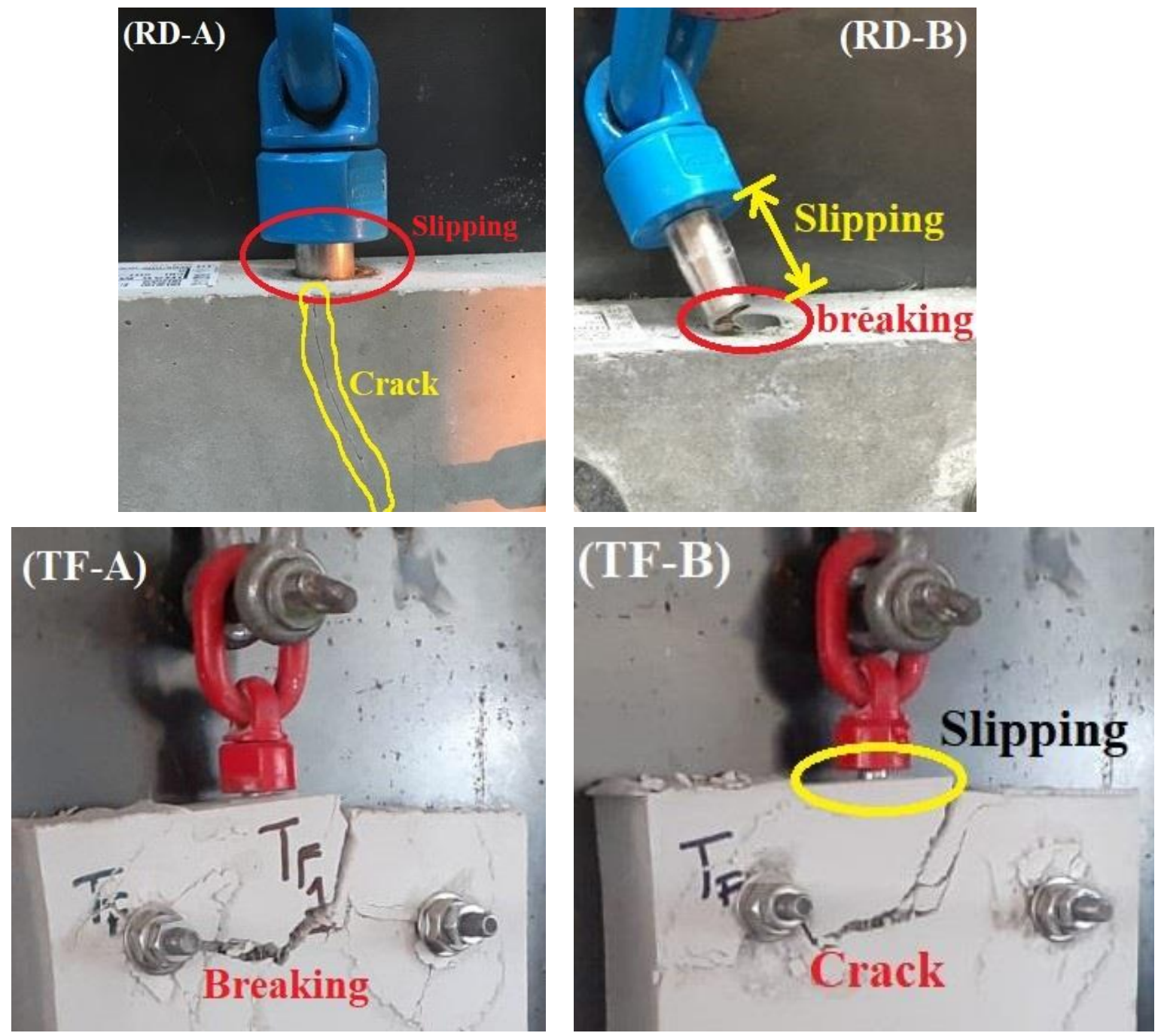

Fig. 4. Damage appearance of RD-A, RD-B, TF-A and TF-B samples after pull-out test.

Bond stress between concrete and socket can be calculated from the tensile load values obtained as a result of pull-out test. Using the ultimate tensile loads in this study, bond stress has been calculated from Equation 1 , assuming an even bond stress distribution along the bond length. In this equation, $\tau_{\max }$ is the bond strength, MPa; P is the ultimate pull-out load, $\mathrm{kN}$; $\mathrm{d}$ is the socket diameter, mm; and la is the bond length, mm.

$$
\tau_{\max }=\frac{P}{\pi \cdot d \cdot l_{a}}
$$

Maximum pull-out loads and bond stress values are compared according to two different mixtures and sockets in Fig. 5. The bond stress between the RD socket and the B mix was $13 \%$ higher compared to the A mix. Also the bond stress between the TF socket and the B mix was 39\% higher compared to the A mix. This situation is parallel to the pull-out loads obtained for two different mixtures. While the maximum pullout loads of RD sockets are higher compared to TFs, the bond stress values on the contrary are obtained as low. The reason why RDs have high maximum pull-out loads is that these sockets are longer compared to 
TFs. The reason why TFs have high bond stress is due to the notch on the ends of these sockets. Of course, the reason why the bond stress of RD is half low may be that the diameter of the RD socket is thin. The bond length of TF was $23 \%$ of RD, the maximum pull-out load was $56 \%$ and the bond stress was $195 \%$. Bond stress between a steel bar and concrete is affected by the interaction between the bar and cement, cracks in the concrete and steel fibers in the concrete mixture. Due to these factors at the beginning of the loading, the bar resists elusion, but after reaching the maximum bond-stress, it is stripped from the concrete with a constant friction coefficient [23]. Bond between reinforcement and concrete is measured as a shear stress, or bond stress, at the interface between the two mate- rials, distributed over the surface of the rebar along the embedded length. Following this definition, bond stress is the ratio between the rate of change in axial force along the rebar and the area of rebar surface over which this change takes place. In addition to this shear stress there are other aspects involved, especially in the case of deformed, ribbed rebars [24,25]. A shear component, parallel to the rebar axis, and a radial component which affects the sur- rounding concrete. Therefore, bond implies not only bond stresses but radial stresses as well [13].

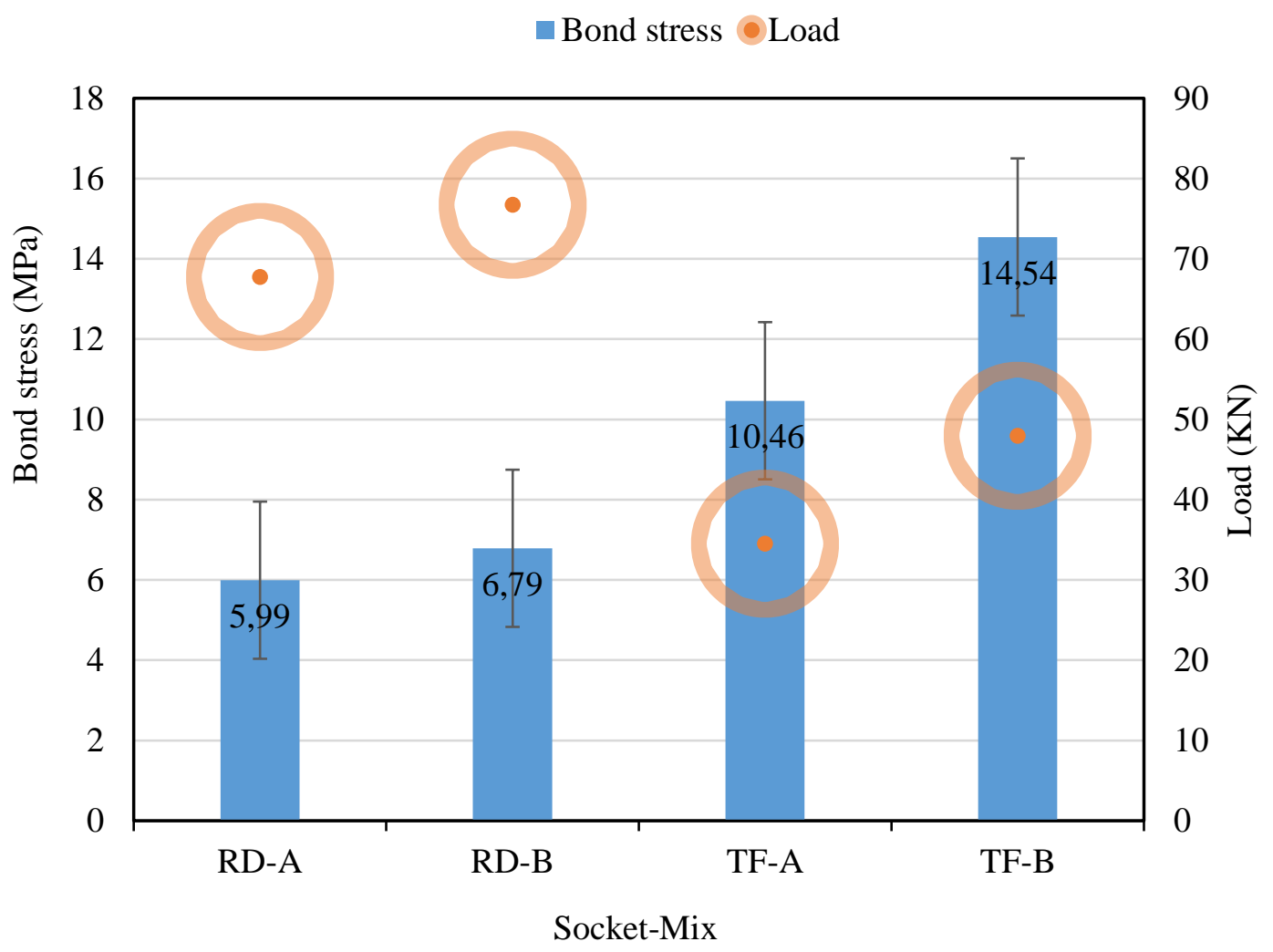

Fig. 5. Comparison of bond stress and lifting load on RD and TF sockets.

The behavior of two different types of socket against shear load is compared in Fig. 6. When the results are evaluated in terms of minimum-maximum values, a parallelism is observed with the pull-out test results. This applies to both load and displacement. RD socket carried 16\% higher shear load in the B mix compared to the A mix. Also TF socket carried 4\% higher shear load in the B mix compared to the A mix. Considering the displacement results in shear loading, the displacement value of the RD socket was $31 \%$ higher in the A mix than the B mix. Also, the displacement value of the TF socket was $27 \%$ higher in the B mix than the A mix. When examined according to different socket types in the same mixture, it has been observed that both sockets in the A mixture bear the same load. Also, it was shown that the RD socket carries $11 \%$ more load than the TF socket in the B mixture. Similarly, when displacement values are examined according to 
the same mixtures, the RD socket showed $91 \%$ more displacement in the A mixture than the TF socket. Also, $14 \%$ more displacement of the RD socket was observed in the B mixture compared to the TF socket. Fluctuations in force-displacement curves are caused by fibers in concrete. This was also noticed by the sound of the fibers being broken in tandem during the test. When the shear force coincides with the large volume of the fibers, larger peaks are formed in the downward curves with the breaking of the fibers after a certain strength.

In this study, the socket pull-out and shear tests of the experimentally investigated plate samples were subjected to higher loads than the loads carried in practice. The load that the sockets are exposed to during transport and assembly is only the loads of the precast plates themselves. The values obtained from the pullout and shear test results can be used for the production of larger sized precast plates in future studies.

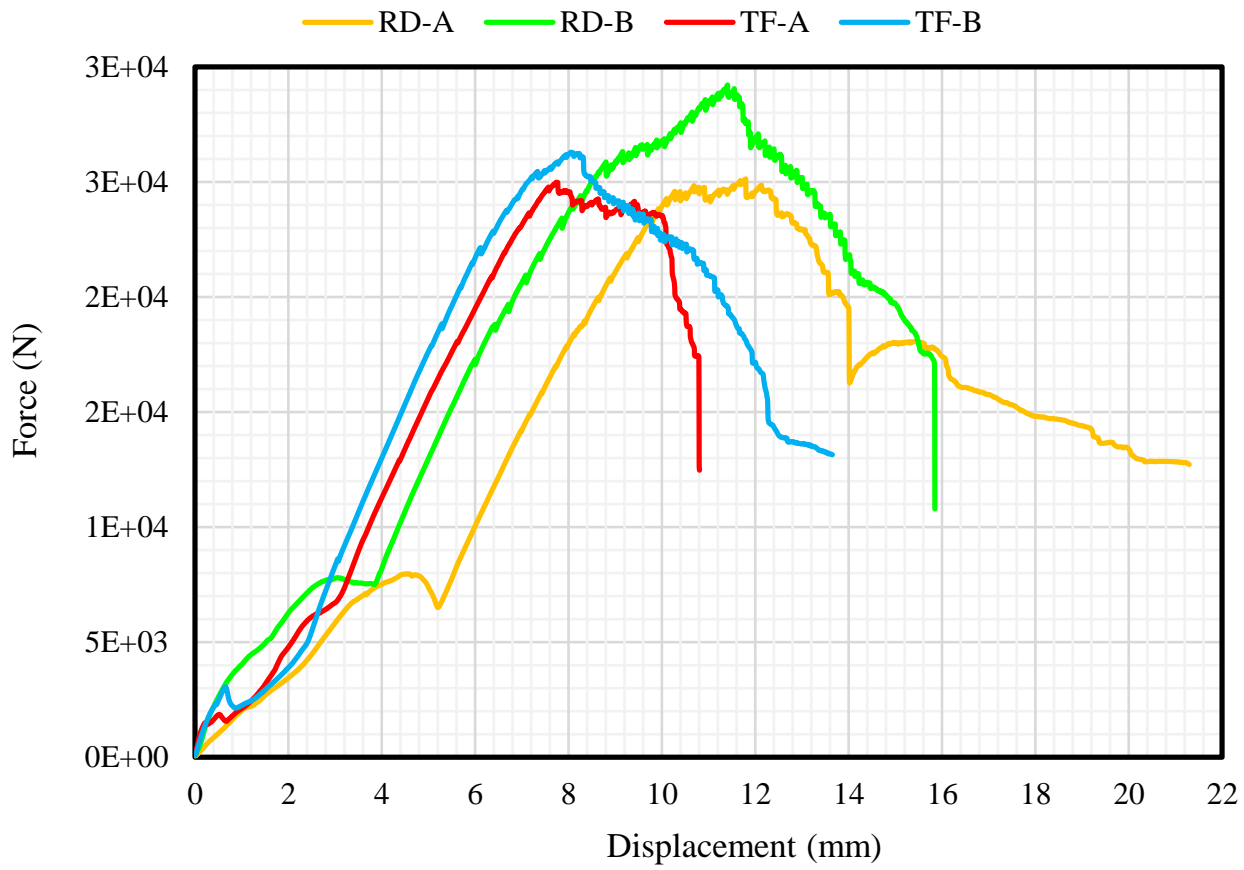

Fig. 6. Force-displacement curves of two different lifting sockets after shear test.

The shear test is generally designed to indicate the shear strength of UHPC panels, not sockets. The damage to the samples after testing is shown in Fig. 7. The reason why the test setup was designed in this way is to specify the strength of the samples in case they are lifted in this way at the construction site. The reason for the gap in the middle of the steel support placed on the sample is that the socket and the concrete surrounding the socket can be released while the shear force is applied.

When the RD-A and RD-B samples are examined, it is observed that RD-A is more deformed although RD-B carries more load. In the RD-A sample, the socket suddenly suffered fiber breakage after displacement of $5 \mathrm{~mm}$. This case during $7.3 \mathrm{kN}$ loading and visible cracks occurred in the concrete. For this reason, there was a decrease in the loading, then other fibers stepped in and the load amount increased up to $25 \mathrm{kN}$. After reaching this level of load, the bond between the socket and the concrete was completely lost and the specimen became completely deformed from both sides of the socket, as seen in Fig. 7. Considering the damage condition of the RD-B sample, it is understood that it is more elastic and stronger than the other mixture, as seen in the curve in Fig. 6. Similarly, strength loss was observed in the RD-B sample after $4 \mathrm{~mm}$ displacement, then the load amount exceeded $28 \mathrm{kN}$ by effect of other fibers surrounding the sockets. In addition, while the RD-A specimen fractured more symmetrically and softly, RD-B was deformed on one side. This is again due to the compactness of the B-mixture and the intervention of the fibers against breakage. When the damage conditions of the samples containing TF socket were examined, 
the damage status of TF-A was observed more than TF-B due to the strength of the B mixture. The loaddisplacement behavior of this socket also confirmed this in two different mixtures.
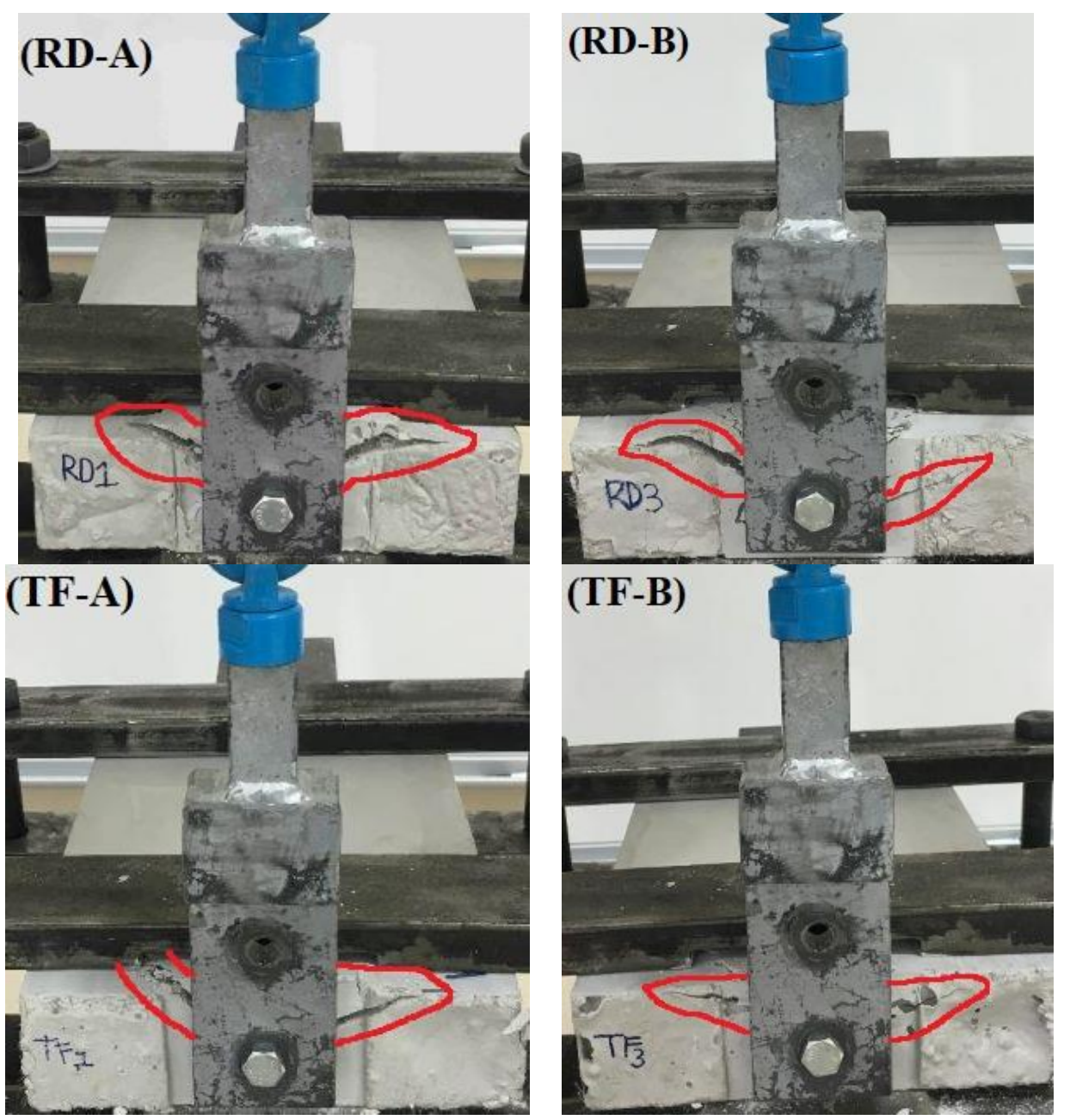

Fig. 7. Damage appearance of RD-A, RD-B, TF-A and TF-B samples after shear test.

\section{CONCLUSIONS}

In the present study, based on experimental test methods, the behavior of two different types of lifting sockets embedded in real-size UHPC precast panels against pull-out and shear loads was investigated. Two different mixtures, A and B, were used as the UHPC mixture, and three samples were produced for each test and average results were obtained. Bond stress behavior was evaluated according to socket type and mixture properties. The following results can be obtained from the data obtained.

When the compressive and flexural strengths of the produced UHPC samples were compared with the literature, it was found that the results were satisfactory. It is stated that the compressive strength of UHPC elements used in building facades is generally above $100 \mathrm{MPa}$. The compressive strengths of the A and B mixtures used in this study provide this criterion as 116 and $140 \mathrm{MPa}$, respectively.

The RD socket showed a maximum pull-out load capacity of $67 \mathrm{KN}$ in the A mixture and $76 \mathrm{KN}$ in the B mixture. TF socket showed 22 and $47 \mathrm{KN}$, respectively. The B mixture, which has high compressive and 
bending strength, exhibited superior results compared to the A mixture due to its high adhesion and friction feature with the socket in pull-out tests. Bond stresses of RD and TF sockets were also calculated, and TF was obtained approximately 2 times higher than RD. It was explained that this was due to the notch on the ends of the TF sockets.

According to the shear test results, the RD socket withstood a load of 24 and $29 \mathrm{KN}$, respectively, in the mixture of A and B. For the TF socket, $25 \mathrm{KN}$ and $26 \mathrm{KN}$ shear forces were recorded, respectively, in the same mixtures. According to the pull-out and shear test results, mix B exhibited higher displacement for both sockets compared to mix A.

As a result, the suitability of both sockets used in the Project in terms of safety has been confirmed. The results particularly proved that RD sockets can be used as lifting sockets for larger precast plates to be produced from the same mixtures. This study may be useful in the safety examination of the lifting socket, mounting apparatus and other embedded additional elements that are planned to be implemented for precast UHPC facade elements in the future.

\section{ACKNOWLEDGEMENT}

In this study, we would like to thank Fibrobeton Company and R\&D personnel who contributed to material supply, test production and some tests

\section{REFERENCES}

[1] A. TOPBAS, F.Ö. TULEN, M. MARASLI, B. KOHEN, A Prefabricated GFRC-UHPC Shell Pedestrian Bridge, IASS Annual Symposium 2019 - Structural Membranes. (2019).

[2] A. TOPBAS, T. Ateser, F.O. TUlen, M. MARASLI, B. KOHEN, Physical Modeling and Design Development of Precast UHPC Shell Bridge, Proceedings of the IASS Annual Symposium 2020/21 and the 7th International Conference on Spatial Structures. (2020).

[3] J. Xue, B. Briseghella, F. Huang, C. Nuti, H. Tabatabai, B. Chen, Review of ultra-high performance concrete and its application in bridge engineering, Construction and Building Materials. 260 (2020) 119844. https://doi.org/10.1016/j.conbuildmat.2020.119844.

[4] P. Richard, M. Cheyrezy, S.D. Bouygues, S. Quentin, (Refereed) (Received January 5: in final form April 12.1995), 25 (1995) 1501-1511.

[5] J. Li, Z. Wu, C. Shi, Q. Yuan, Z. Zhang, Durability of ultra-high performance concrete - A review,

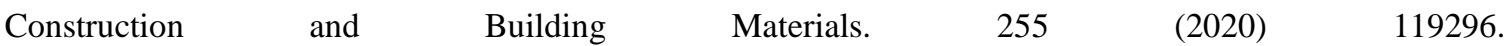
https://doi.org/10.1016/j.conbuildmat.2020.119296.

[6] M. Ghous, R. Kahraman, N. Al, B. Gencturk, Durability characteristics of high and ultra-high performance concretes, Journal of Building Engineering. 33 (2021) 101669. https://doi.org/10.1016/j.jobe.2020.101669.

[7] N. Roux, C. Andrade, M.. Sanjuan, Experimental study of durability of reactive powder concretes, (1996) 16.

[8] M. MOHABBI, S. VAROLGÜNEŞ, Manyetize Edilmiş Suyun, RPB Betonların Özellik ve Davranışları Üzerindeki Etkisi, Bilecik Şeyh Edebali Üniversitesi Fen Bilimleri Dergisi. 6 (2019) 21-29. https://doi.org/10.35193/bseufbd.559662. 
[9] M. Seis, S. Subasi, B. Isbilir Kula, M. Marasli, Karbon nanotüplerin ultra yüksek performanslı betonların Mekanik ve fiziksel özelliklerine etkileri, Cumhuriyet Zirvesi ,4. Uluslararası Uygulamalı Bilimler Kongresi. (2021) 148-157.

[10] H.H. Abrishami, D. Mitchell, Simulation of Uniform Bond Stress, Materials Journal. 89 (1992) 161-168.

[11]D. Gao, H. Yan, D. Fang, L. Yang, Bond strength and prediction model for deformed bar embedded in hybrid fiber reinforced recycled aggregate concrete, Construction and Building Materials. 265 (2020) 120337. https://doi.org/10.1016/j.conbuildmat.2020.120337.

[12] J. Eiras-López, S. Seara-Paz, B. González-Fonteboa, F. Martínez-Abella, Bond Behavior of Recycled Concrete: Analysis and Prediction of Bond Stress-Slip Curve, Journal of Materials in Civil Engineering. 29 (2017) 04017156. https://doi.org/10.1061/(asce)mt.1943-5533.0002000.

[13]E. Garcia-Taengua, J.R. Martí-Vargas, P. Serna, Bond of reinforcing bars to steel fiber reinforced concrete, $\begin{array}{llllll}\text { Construction } & \text { and } & \text { Building } & \text { Materials. } & 105 & \text { (2016) }\end{array}$ https://doi.org/10.1016/j.conbuildmat.2015.12.044.

[14] ASTM C900, Standard test method for pullout strength of hardened concrete., American Society for Testing and Materials West Conshohocken, USA. (2013).

[15] ACI 4403 R, Guide test methods for FRPs for reinforcing or strengthening concrete structures., Michigan, USA: American Concrete Institute. (2004).

[16]CAN/CSA S806, Design and construction of building components with fibre reinforced polymers., Toronto, Canada: Canadian Standards Association. (2002).

[17] ASTM C234-91a, Standard Test Method for Comparing Concretes on the Basis of the Bond Developed with Reinforcing Steel, American Society for Testing and Materials West Conshohocken, PA, 1991. (2000).

[18]C 1611/C 1611M, Standard Test Method for Slump Flow of Self-Consolidating Concrete, American Society for Testing and Materials. (205AD).

[19]ASTM C1856/C1856M-17, Standard Practice for Fabricating and Testing Specimens of Ultra-High Performance Concrete, American Society for Testing and Materials. (2017).

[20] T.A. Söylev, The effect of fibers on the variation of bond between steel reinforcement and concrete with casting position, Construction and Building Materials. 25 (2011) 1736-1746. https://doi.org/10.1016/j.conbuildmat.2010.11.093.

[21] Ş. Yazici, H.Ş. Arel, The effect of steel fiber on the bond between concrete and deformed steel bar in SFRCs, $\begin{array}{llllll}\text { Construction } & \text { and } & \text { Building } & \text { Materials. } & 40 & \text { (2013) }\end{array}$ https://doi.org/10.1016/j.conbuildmat.2012.09.098.

[22]L. Huang, Y. Chi, L. Xu, P. Chen, A. Zhang, Local bond performance of rebar embedded in steelpolypropylene hybrid fiber reinforced concrete under monotonic and cyclic loading, Construction and Building Materials. 103 (2016) 77-92. https://doi.org/10.1016/j.conbuildmat.2015.11.040.

[23]D. Shen, X. Shi, H. Zhang, X. Duan, G. Jiang, Experimental study of early-age bond behavior between high strength concrete and steel bars using a pull-out test, Construction and Building Materials. 113 (2016) 653663. https://doi.org/10.1016/j.conbuildmat.2016.03.094. 
[24]J. Cairns, G.A. Plizzari, Towards a harmonised European bond test, Materials and Structures/Materiaux et Constructions. 36 (2003) 498-506. https://doi.org/10.1617/13887.

[25]P.F. Bamonte, P.G. Gambarova, High-Bond Bars in NSC and HPC: Study on Size Effect and on the Local Bond Stress-Slip Law, Journal of Structural Engineering. 133 (2007) 225-234. https://doi.org/10.1061/(asce)0733-9445(2007)133:2(225). 